\title{
Comparison of physical and qualitative traits of meat of two Polish conservative flocks of ducks*
}

\begin{abstract}
In two Polish conservative flocks of Miniduck (K2) and Pekin (P33), registered by FAO as domestic genetic resources (World Watch List, 2000) the mean values of physical (tissue components) and qualitative traits of meat $\left(\mathrm{pH}_{15}, \mathrm{pH}_{24}\right.$, colour of meat) were determined. The experimental flocks showed significant variations in body weight at 7 weeks of age (1540 vs 2088 in drakes and 1395 vs $1986 \mathrm{~g}$ in ducks), in the proportion of breast and leg muscles and skin with subcutaneous fat in eviscerated carcass. K2 ducks are characterized by outstanding musculature of breast and P33 ducks by that of lower leg and by low fatness.

$\mathrm{pH}_{15}$ values of breast and leg muscles in $\mathrm{K} 2$ and $\mathrm{P} 33$ birds were greater than $\mathrm{pH}_{24}$ of these muscles. In both flocks $\mathrm{pH}_{15}$ values of 6.09 to 6.33 and $\mathrm{pH}_{24}$ values of 5.90 to 6.05 in breast muscles were lower than in leg muscles (6.33 to 6.46 and 6.12 to 6.37 , respectively). A significantly lower L* value (darker colour) of breast muscle was characteristic of K2 birds (43.7 in males and 40.5 in females) compared to P33 males and females. Furthermore, breast muscles of K2 drakes and ducks had significantly higher redness ( $\left.\mathrm{a}^{*}\right)$ and yellowness values (b*) than P33. In pectoralis superficialis muscle of K2 and P33 females, a significantly lower diameter was found for white muscle fibres $(\alpha \mathrm{W})(30.0$ to $30.5 \mu \mathrm{m})$ and for red muscle fibres $(\beta \mathrm{R})(16.9$ to $17.6 \mu \mathrm{m})$ than in biceps femoris muscle ( $\alpha \mathrm{W}$ from 48.3 to 54.2 ; $\beta \mathrm{R}$ from 36.0 to $37.1 \mu \mathrm{m}$ ). Muscle fibres of $\mathrm{K} 2$ compared to P33 ducks were characterized by significantly greater diameters of $\beta \mathrm{R}$ muscle fibre in pectoralis superficialis muscle, and by lower $\alpha \mathrm{W}$ and $\beta \mathrm{R}$ fibre diameters in biceps femoris muscle. The experiment showed that meat of ducks from the conservative flocks studied is valuable from the consumer's point of view.
\end{abstract}

Key Words: biodiversity, duck, meat traits

\section{Zusammenfassung}

Titel der Arbeit: Vergleich physischer und qualitativer Eigenschaften des Fleisches zweier polnischer bodenständiger Entenarten

In zwei bodenständigen polnischen Entenarten [Minienten (K2) und Pekingenten (P33)], die von der FAO als genetische Ressourcen (World Watch List, 2000) registriert sind, wurden physische (Gewebebestandteile) und qualitative Eigenschaften des Fleisches $\left(\mathrm{pH}_{15}, \mathrm{pH}_{24}\right.$, Fleischfarbe) bestimmt. Die untersuchten Populationen zeigten im Alter von 7 Wochen signifikante Unterschiede im Körpergewicht (1540 bzw. 2088 g bei Erpeln und 1395 bzw. 1986 g bei Enten), in der Brust und Beinmuskulatur sowie im Anteil an subkutanem Fett. K2-Enten hatten eine hervorragende Brustmuskulatur und P33-Enten wiesen geringere Fettanteile aus.

Die $\mathrm{pH}_{15}$ Werte der Brust- und Beinmuskulatur in $\mathrm{K} 2$ und P33 waren höher als $\mathrm{pH}_{24}$ bei diesen Muskeln. In beiden Entenarten waren die $\mathrm{pH}_{15}$ und $\mathrm{pH}_{24}$ Werte der Brustmuskulatur niedriger als in der Beinmuskulatur.

Die Brustmuskulatur von K2 Erpeln und Enten zeigte signifikant dunklere Färbungen als bei P33. In beiden Entenarten war der Durchmesser der weißen und roten Muskelfasern im pectoralis superficialis Muskel signifikant kleiner als im biceps femoris Muskel.

Schlüsselwörter: Biodivergenz, Ente, Fleischeigenschaften

\section{Introduction}

Threatened species conservation programmes include not only animals living in natural habitats, but also breeds, line and varieties of domestic animals bred by man. Interbreed variation accounts for half of overall genetic variation within each species (MAIJALA, 1994). Among the many reasons behind species conservation are

* This work was conducted as part of the research project no 3 PO6Z 00422 financed by the State Committee for Scientific Research 
economic, biological, scientific, cultural and even emotional aspects (CRAWFORD, 1993). Conservation of domestic animal diversity (DAD) is related to both current and future breeding needs. Thanks to management of birds in conservative or genetic reserve flocks, their genetic variation and yet undetected markers of different traits can be preserved. Conservative flocks of ducks conserved in situ are a source of genetic variation, which is, among others, a condition of further breeding work (KSIAZŻKIEWICZ and MAZANOWSKI, 1984).

The world's genetic resources conservation programme (World Watch List - FAO, 2000) includes two Polish duck populations - Miniducks (K2) and Pekin ducks (P33). These flocks were described in terms of origin, conformation characteristics, and reproductive and meat performance by KSIĄŻKIEWICZ (2002), who showed that P33 ducks are characterized by satisfactory body weight, low carcass fatness, high nutritive value of meat and good feather quality. Miniducks are characterized by outstanding musculature of breast and very good parameters of duckling hatchability. However, no microstructural studies of pectoralis superficialis and biceps femoris muscles have been conducted so far in conservative flocks. Earlier histological studies only included one synthetic group of general-purpose ducks and ducks of a breeding strain (KŁOSOWSKA et al., 1999). It is suggested that meat qualitative studies should include traits that had never been determined in conservative flocks (colour and $\mathrm{pH}$ among others) and contribute to the consumers' evaluation of meat quality.

The present study was designed to compare two Polish conservative flocks for selected physical and qualitative traits of meat of 7-week-old ducks.

\section{Material and Methods}

The experiment involved ducks from two conservative flocks, registered in the FAO World Watch List (2000) and conserved in situ at the Department of Waterfowl Breeding Dworzyska, belonging to the National Research Institute of Animal Production in Kraków, Poland:

- K2 Miniducks, i.e. crosses of mallard (Anas platyrhynchos L.) and Pekin ducks (KSIĄŻKIEWICZ, 1982),

- Polish Pekins P33.

Until 7 weeks of age, birds were kept in a standard windowless poultry facility with no access to the outside yard. The housing system was in accordance with the rules of duck raising (KSIĄŻKIEWICZ, 2003). Each flock had 60 birds, i.e. 30 males and 30 females. Ducks were fed on an ad libitum basis with a complete mixture containing 11.83 MJ metabolizable energy and $18.3 \%$ crude protein until 3 weeks of age and 11.15 MJ metabolizable energy and $17.85 \%$ crude protein until 7 weeks of age. All birds were weighed at 7 weeks on an electronic balance to an accuracy of 5 g. Based on average body weights of drakes and ducks, 6 males and 6 females were selected from each flock. Twelve hours before slaughter, birds were only allowed access to water. After slaughter, birds were defeathered and eviscerated and their carcasses were cooled within $24 \mathrm{~h}$ to $4^{\circ} \mathrm{C}$. Cooled carcasses were dissected and muscle traits evaluated for quality. Carcasses were eviscerated into breast muscles, thigh and lower thigh muscles, skin with subcutaneous fat and abdominal fat, which were weighed on an electronic balance to an accuracy of $1 \mathrm{~g}$.

Qualitative assessment of the muscles was performed based on $\mathrm{pH}$ value of breast and leg muscles 15 min postmortem $\left(\mathrm{pH}_{15}\right)$ and after 24-h cooling $\left(\mathrm{pH}_{24}\right) . \mathrm{pH}$ 
measurements were taken with a glass electrode connected with a Cyberscan $\mathrm{pH}$ meter. Colour of pectoralis superficialis muscle was measured with a photocolorimeter (Chroma Meter CR 310, Minolta) using the Hunter colour scale ( $\mathrm{L}^{*} \mathrm{a} \mathrm{b}^{*}$ ). L* was assumed to be a lightness variable on a scale from 0 for an ideal black to 100 for an ideal white, $\mathrm{a}^{*}$ represented the degree of redness (if positive) or greenness (if negative), and $b^{*}$ represented the degree of yellowness (if positive) or blueness (if negative) (WOŁOSZYN, 2002).

Fibre microstructure was analysed with pectoralis superficialis and biceps femoris muscles obtained from K2 and P33 females. After the ducks were slaughtered and exsanguinated, sections of muscles were taken and frozen in liquid nitrogen at $-196^{\circ} \mathrm{C}$. Slices of $10-\mu \mathrm{m}$ thickness were cut using a cryostat. To distinguish two types of muscle fibres - light blue and dark blue according to DUBOWITZ et al. (1973) or white $(\alpha \mathrm{W})$ and red $(\beta \mathrm{R})$ according to ASHMORE and DOERR (1971) - reactions for the activity of succinate dehydrogenase were performed. The specimens were evaluated under a microscope at 150× magnification to determine the dimensions of the smallest diameters for 200 fibres (both $\alpha \mathrm{W}$ and $\beta \mathrm{R}$ ) following the Brooke method (1970). Cross-sections of pectoralis superficialis and biceps femoris muscles were printed out using a microscopic image analysis system (Leica Q500 MC) after previously placing each randomly selected specimen under an optical microscope (Nicon). In the cross-sections of muscles presented as Figures 1 to 4 fibres $\alpha \mathrm{W}$ are brighter and fibres $\beta \mathrm{R}$ darker.

The data were analysed statistically (x, $\mathrm{v} \%$ ) for one-way analysis of variance and significance of differences. The results were processed with the ANOVA module of Statistic.

Table 1

Comparison of 7-week-old ducks for mean body weights, dressing percentage and content of selected carcass tissue components in two conservative flocks (Vergleich des mittleren Körpergewichts, des Anteils von Brust und Beinmuskeln und des Gehalts an subkutanem Fett in ausgenommenen Körpern bei zwei konservativen Entenarten im Alter von 7 Wochen)

\begin{tabular}{|c|c|c|c|c|c|c|c|c|}
\hline \multirow[b]{2}{*}{ Flock } & \multirow{2}{*}{\multicolumn{2}{|c|}{ Sex }} & \multirow[b]{2}{*}{$\begin{array}{l}\text { Body } \\
\text { weight } \\
\text { (g) }\end{array}$} & \multirow[b]{2}{*}{$\begin{array}{c}\text { Dressing } \\
\text { percentage } \\
\text { (\%) }\end{array}$} & \multicolumn{4}{|c|}{ Proportion in eviscerated carcass with neck (\%) } \\
\hline & & & & & breast muscles & $\begin{array}{c}\text { leg } \\
\text { muscles }\end{array}$ & $\begin{array}{c}\text { skin with } \\
\text { subcutaneous } \\
\text { fat }\end{array}$ & abdominal fat \\
\hline \multirow{4}{*}{ K2 } & \multirow{4}{*}{0} & $\bar{x}$ & $1540 * \mathrm{~b}$ & $68.1^{\mathrm{a}}$ & $11.3 *^{\mathrm{a}}$ & $14.0 * \mathrm{~b}$ & $28.1^{\mathrm{a}}$ & $2.2^{\mathrm{a}}$ \\
\hline & & 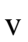 & 1.7 & 1.6 & 6.6 & 7.9 & 3.9 & 28.9 \\
\hline & & $\mathrm{x}$ & $1395^{\mathrm{b}}$ & $69.4^{\mathrm{a}}$ & $13.1^{\mathrm{a}}$ & $12.6^{\mathrm{b}}$ & $28.5^{\mathrm{a}}$ & $2.5^{\mathrm{a}}$ \\
\hline & & $\mathrm{v}$ & 2.2 & 2.4 & 17.2 & 9.3 & 9.7 & 17.0 \\
\hline \multirow{4}{*}{ P33 } & \multirow{2}{*}{$\hat{\sigma}$} & $\mathrm{X}$ & $2088 *^{\mathrm{a}}$ & $69.5^{\mathrm{a}}$ & $8.2 *^{\mathrm{b}}$ & $16.5^{\mathrm{a}}$ & $25.3^{b}$ & $1.2^{b}$ \\
\hline & & $\mathrm{V}$ & 2.8 & 2.7 & 15.8 & 6.6 & 5.1 & 35.2 \\
\hline & \multirow{2}{*}{ q } & $\mathrm{x}$ & $1986^{\mathrm{a}}$ & $69.6^{\mathrm{a}}$ & $10.1^{\mathrm{b}}$ & $15.9^{\mathrm{a}}$ & $23.9^{b}$ & $1.3^{\mathrm{b}}$ \\
\hline & & V & 2.6 & 2.0 & 9.7 & 2.3 & 5.5 & 23.2 \\
\hline
\end{tabular}

* Values between males and females in a flock differ significantly; Values in columns between flocks, separately for sexes, marked with different letters differ significantly $(\mathrm{P} \leq 0.05)$

\section{Results}

Body weights of 7-week-old males compared to females were significantly greater in K2 and P33 (Table 1). Females from both groups had greater dressing percentage than males (non-significant difference), greater proportion of breast muscles and skin with subcutaneous fat and abdominal fat in carcass, and lower proportion of leg muscles. 
Body weights of K2 males and females were significantly lower than those of P33 ducks. Dressing percentage in both flocks was high and ranged from $68.1 \%$ in $\mathrm{K} 2$ males to $69.6 \%$ in P33 females. The proportion of breast muscles in K2 ranged from $11.3 \%$ in males to $13.1 \%$ in females and was significantly greater than in P33 birds at 8.2 and $10.1 \%$ respectively. Carcasses of K2 birds compared to P33 ducks were characterized by a greater percentage of skin with subcutaneous fat and of abdominal fat, and a lower percentage of leg muscles.

Table 2

Comparison of meat qualitative traits of 7-week-old ducks from two conservative flocks (Vergleich der Fleischqualitätseigenschaften bei zwei konservativen Entenarten im Alter von 7 Wochen)

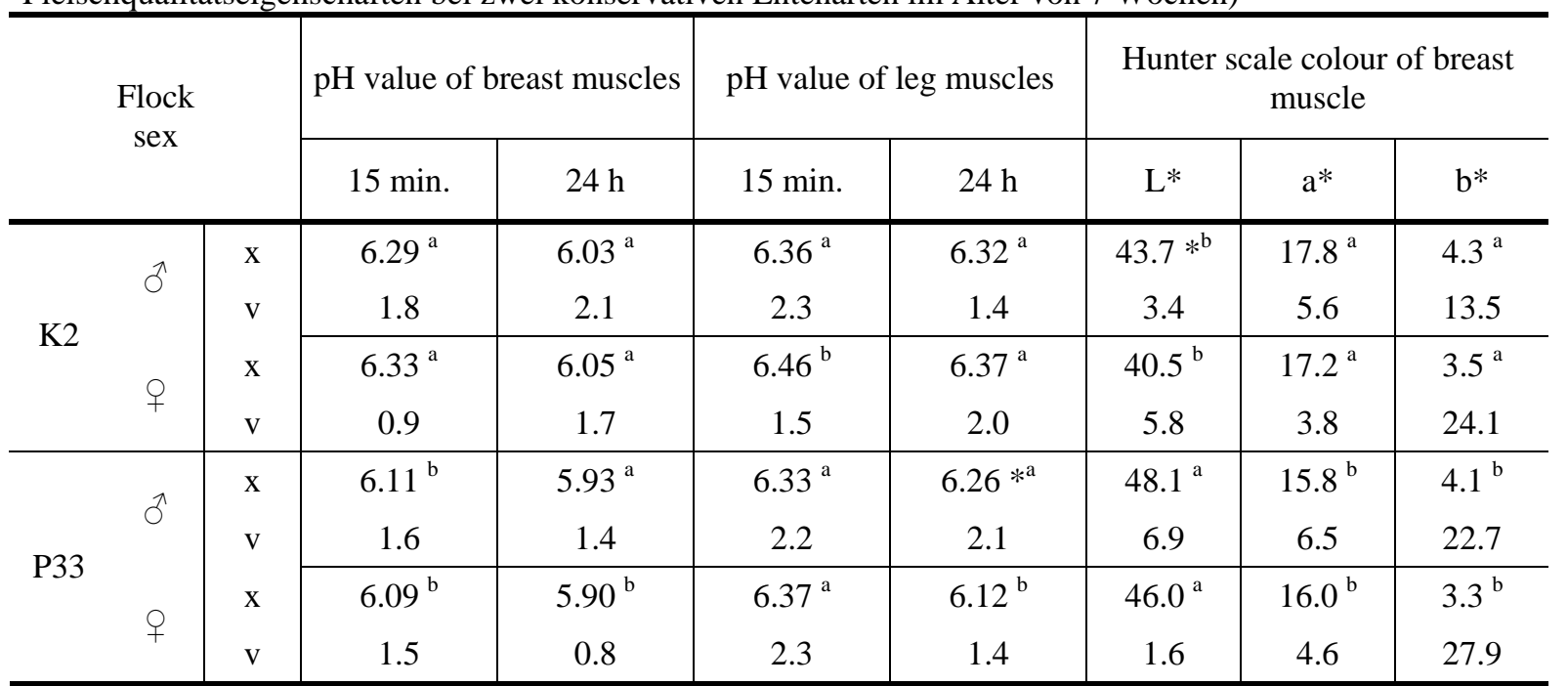

* Values between males and females in a flock differ significantly $(\mathrm{P} \leq 0.05)$

Values in columns between flocks, separately for sexes, marked with different letters differ significantly ( $\mathrm{P} \leq 0.05)$

$\mathrm{pH}_{15}$ and $\mathrm{pH}_{24}$ values determined in breast muscles in both flocks were lower than in leg muscles (Table 2). $\mathrm{pH}_{15}$ values of breast muscles, measured 15 min postmortem, ranged from 6.11 (P33) to 6.29 (K2) in males, and from 6.09 (P33) to 6.33 (K2) in females. After the carcasses were cooled, muscle $\mathrm{pH}_{24}$ values were lower, from 5.93 (P33) to 6.03 (K2) in males and from 5.90 (P33) to 6.05 (K2) in females. In leg muscles, a higher $\mathrm{pH}_{15}$ value was characteristic of $\mathrm{K} 2$ drakes and ducks (6.36 and 6.46 respectively), and a lower $\mathrm{pH}_{15}$ value was noted in $\mathrm{P} 33$ ducks (from 6.33 in males to 6.37 in females). A similar relationship was found for $\mathrm{pH}_{24}$, because higher values were determined in leg muscles of $\mathrm{K} 2$ drakes and ducks (6.32 and 6.37) and lower ones in P33 males and females (6.26 and 6.12 respectively). A significantly lower $\mathrm{L}^{*}$ value (darker colour) of breast muscle was characteristic of K2 birds (43.7 in males and 40.5 in females), while P33 males and females had a lighter meat colour at 48.1 and 46.0 (Table 2). Breast muscles of K2 drakes and ducks were characterized by significantly higher redness $\left(\mathrm{a}^{*}\right)$ and yellowness values $\left(\mathrm{b}^{*}\right)$ compared to the muscles of P33 ducks.

Based on microstructural analysis of the muscles in K2 and P33 females (Table 3, Fig. $1-4)$, a lower diameter of white $(\alpha \mathrm{W})$ and red muscle fibres $(\beta \mathrm{R})$ was found in pectoralis superficialis than in biceps femoris muscle. Muscle fibres of K2 ducks compared to P33 were characterized by significantly greater diameters of $\beta R$ fibres in pectoralis superficialis muscle, and lower diameters of $\alpha \mathrm{W}$ and $\beta \mathrm{R}$ fibres in biceps femoris muscle. 
Table 3

Comparison of white $(\alpha \mathrm{W})$ and red muscle fibre ( $\beta \mathrm{R})$ diameters in pectoralis superficialis and biceps femoris muscles of 7-week-old ducks from two conservative flocks (Vergleich des Durchmessers der weißen $(\alpha \mathrm{W})$ und roten ( $\beta \mathrm{R})$ Muskelfasern im pectoralis superficialis und biceps femoris Muskel bei zwei konservativen Entenarten im Alter von 7 Wochen)

\begin{tabular}{|c|c|c|c|c|c|}
\hline \multirow{2}{*}{\multicolumn{2}{|c|}{$\begin{array}{l}\text { Symbol } \\
\text { of group }\end{array}$}} & \multicolumn{2}{|c|}{$\begin{array}{c}\text { Pectoralis superficialis muscle } \\
\text { - muscle fibres }(\mu \mathrm{m})\end{array}$} & \multicolumn{2}{|c|}{$\begin{array}{l}\text { Biceps femoris muscle } \\
\text { - muscle fibres }(\mu \mathrm{m})\end{array}$} \\
\hline & & $\alpha \mathrm{W}$ & $\beta \mathrm{R}$ & $\alpha \mathrm{W}$ & $\beta \mathrm{R}$ \\
\hline \multirow{2}{*}{ K2 } & $X$ & $30.0^{a}$ & $17.6^{\mathrm{a}}$ & $48.3^{b}$ & $36.0^{a}$ \\
\hline & $\mathrm{V}$ & 7.2 & 1.5 & 6.6 & 4.1 \\
\hline \multirow{2}{*}{ P33 } & $\mathrm{x}$ & $30.5^{a}$ & $16.9^{b}$ & $54.2^{a}$ & $37.1^{a}$ \\
\hline & $\mathrm{V}$ & 3.2 & 1.8 & 4.4 & 3.9 \\
\hline
\end{tabular}

Values in columns marked with different letters differ significantly $(\mathrm{P} \leq 0.05)$

\section{Discussion}

Earlier comparisons of various conservative flocks of ducks demonstrated that the analysed populations represented different utility types, i.e. light (K2) and general purpose ducks (P33). Body weight of Miniducks at 7 weeks of age was $33 \mathrm{~g}$ lower in males and $56 \mathrm{~g}$ lower in females compared to that estimated in the flocks based on 10 generations (KSIĄŻKIEWICZ, 2002). With regard to P33 birds, these differences were greater at $384 \mathrm{~g}$ for males and $400 \mathrm{~g}$ for females. Time trends of body weight indicate that in unselected populations body weights were decreased due to the lack of selection (KSIAZŻKIEWICZ, 2002). The low body weight from 1661 to $1894 \mathrm{~g}$ at 8 weeks of age is characteristic of local duck populations that were not selected for this trait (ISGUZAR et al., 2002). The ducks analysed in the present study had lower body weight values than English ducks (POWELL, 1986). POWELL (1986) reported, however, that ducks unselected for increased feed conversion rate weighed less at 7 weeks of age than selected birds.

Ducks from the flocks studied were characterized by considerable dressing percentage that was greater in females than in males. Dressing percentage of P33 ducks was higher than that obtained in this population by KSIAZŻKIEWICZ and KONTECKA (1993) and that determined in Pekin ducks from Hungary, Germany, Russia and the Czech Republic in tests performed at Ivanka on the Danube (Evaluation, 1989). STAŠKO (1990) in 10-week-old males and 8-week-old females of Khaki Campbell, mallard and Pekin hybrids obtained greater dressing percentage of $74 \%$ compared to the results of the conservative flocks studied. KSIAZŻKIEWICZ (2002) based on analysis of 10 generations of K2 and P33 ducks showed in the same flocks a similar tissue composition. A very good musculature of breast in K2 ducks and of legs in P33 ducks, as well as a low proportion of skin with subcutaneous fat in P33 were confirmed.

Qualitative traits of meat, such as $\mathrm{pH}$ value of breast and leg muscles and meat colour had only been investigated in Pekin and Muscovy ducks (SMITH et al., 1992; BAÉZA and LISTRAT, 2001). The present results indicate higher $\mathrm{pH}_{15}$ and $\mathrm{pH}_{24}$ values of breast and leg muscles in Miniducks compared to P33 Pekins and the values of breast muscle colour were different between these flocks. Darker meat colour in Miniducks is characteristic of game and results from the influence of mallard duck blood (KSIĄŻKIEWICZ, 1982). SMITH et al. (1992) in Pekin ducks obtained a greater difference in $\mathrm{pH}$ value for breast muscle, from 6.25 at 25 min postmortem to 5.66 at 24 h postmortem. BAÉZA and LISTRAT (2001) in two Muscovy lines showed, similar to 


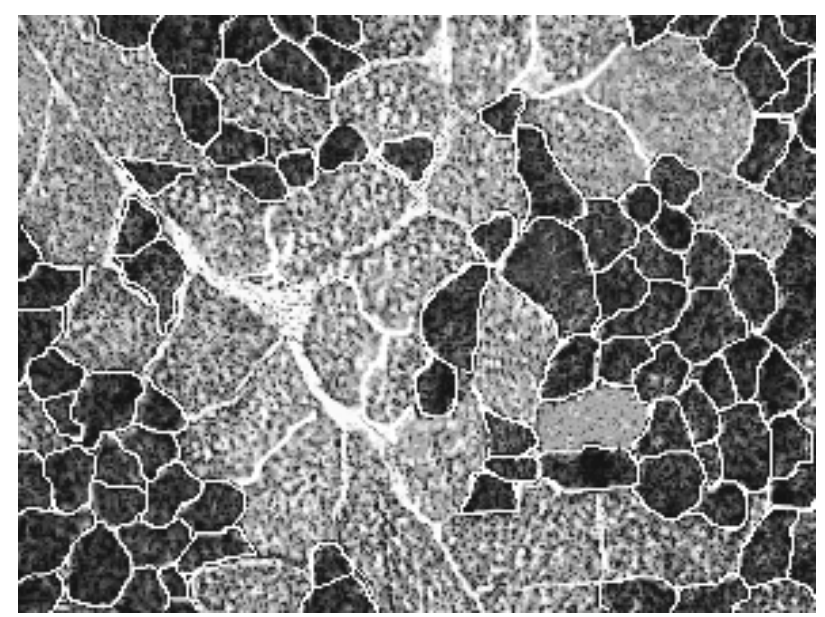

Fig. 1: Cross-section of pectoralis superficialis muscle in $\mathrm{K} 2$ ducks

(Querschnitt des pectoralis superficialis Muskels in K2 Enten)

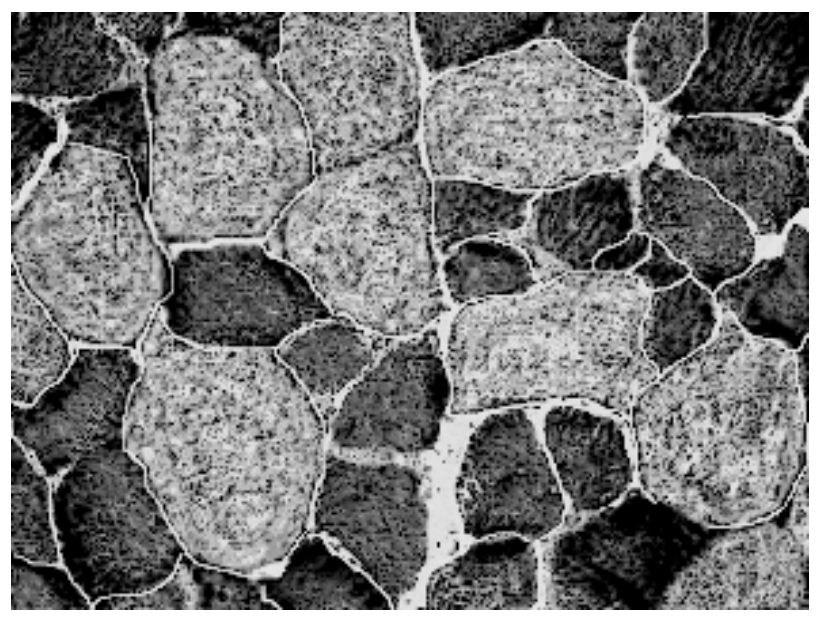

Fig. 2: Cross section of biceps femoris muscle in K2 ducks

(Querschnitt des biceps femoris Muskels in K2 Enten)

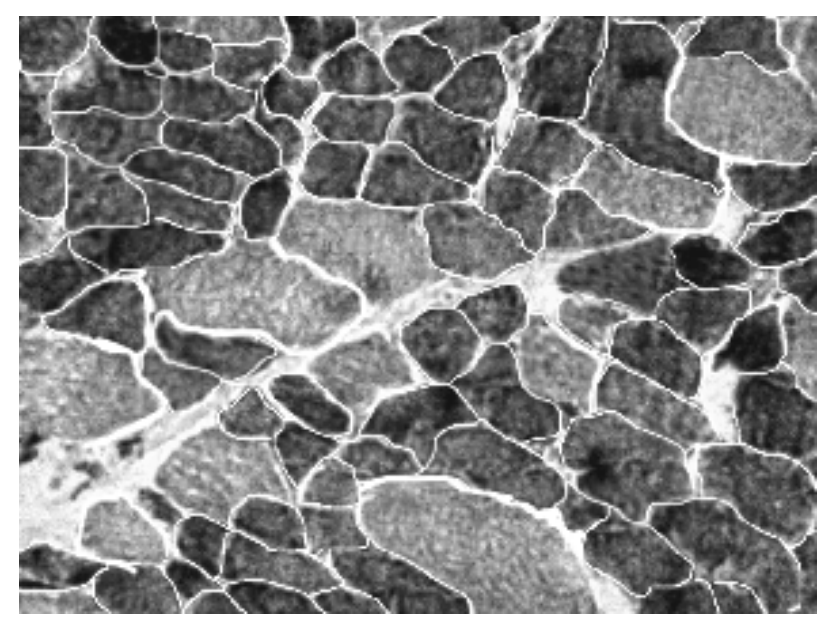

Fig. 3: Cross-section of pectoralis superficialis muscle in P33 ducks

(Querschnitt des pectoralis superficialis Muskels in P33 Enten)

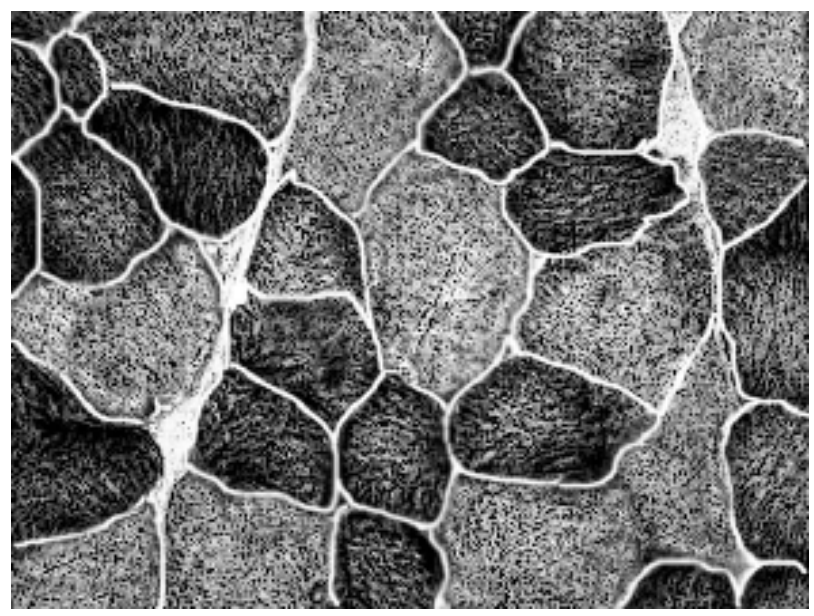

Fig. 4: Cross-section of biceps femoris muscle in P33 ducks

(Querschnitt des biceps femoris Muskels in P33 Enten) 
our data for light ducks, high $\mathrm{pH}_{15}$ values of about 6.40 and lower $\mathrm{pH}_{24}$ values of 5.80 in breast muscles. A similar relationship between $\mathrm{pH}$ values after slaughter $\left(\mathrm{pH}_{15}\right)$ and after carcass cooling $\left(\mathrm{pH}_{24}\right)$ was reported by PINGEL and BIRLA (1981). In 56-dayold ducks, these authors found $\mathrm{pH}$ to decrease from $5.98\left(\mathrm{pH}_{15}\right)$ to $5.85\left(\mathrm{pH}_{24}\right)$ in breast muscles, and from $6.45\left(\mathrm{pH}_{15}\right)$ to $6.33\left(\mathrm{pH}_{24}\right)$ in leg muscles. As reported by PIKUL (1993), glycogen in poultry is more abundant in breast muscles than in leg muscles, making $\mathrm{pH}$ of breast muscles postmortem lower than $\mathrm{pH}$ of leg muscles.

Measurements of meat colour parameters ( $\left.\mathrm{L}^{*}, \mathrm{a}^{*}, \mathrm{~b}^{*}\right)$ in the duck flocks studied varied, but their values did not reveal any meat defects. Breast muscles of ducks evaluated by CHEN et al. (1991) had lower lightness (L* - 31.8) and redness values (a* - 13.4). These authors noted that stress and shyness of birds results in DFD meat. WOŁOSZYN (2002) obtained in Pekin ducks $\times$ Muscovy drakes $L^{*}$ values of about 45. BAEZA et al. (1997) reported darker meat colour in heavy strains of Muscovy ducks ( $L^{*}$ - 35.6). These ducks were characterized by greater $b^{*}(8.40)$ and lower $\mathrm{a}^{*}$ (9.98) values. GIANFALDONI et al. (1994) reported that 12-week-old Muscovy ducks also had darker meat colour ( $\left.\mathrm{L}^{*}-38.2\right)$, but greater redness $\left(\mathrm{a}^{*}-18.8\right)$ and yellowness $\left(b^{*}-6.3\right)$ compared to the birds studied by us. The differences in muscle colour between the ducks compared could result from different muscle myoglobin concentrations. As reported by FLETCHER et al. (1992), breast muscle colour is affected by preslaughter stress, which affects the vascular system of muscles, and thus the concentration and metabolism of heme pigments contained therein. RENERRE (1999), when summarizing many research findings mentions the following factors influencing meat colour: species, sex, age, feeding system, muscle type and $\mathrm{pH}$, muscle thickness, and contents of intramuscular fat and connective tissue in muscle.

The present study confirmed the heterogeneous structure of pectoralis superficialis and biceps femoris muscles in the ducks. The $\alpha \mathrm{W}$ and $\beta \mathrm{R}$ muscle fibre diameters were greater in biceps femoris than in pectoralis superficialis muscle in both K2 and P33. In earlier studies with other Polish genetic reserve strains of ducks and their hybrids, a similar pattern was shown by GÓRSKI (1995). When evaluating the diameter of muscle fibres without division into white and red fibres, at 8 weeks of ducks' age he found a lower thickness of pectoralis superficialis muscle (18.6 to $27.1 \mu \mathrm{m}$ ) compared to thickness of biceps femoris muscle (50.0 to 74.0 $\mu \mathrm{m})$. BIESIADA-DRZAZGA et al. (2000) found in A44 pedigree ducks greater diameters of muscle fibres in pectoralis superficialis muscle $(25.2 \mu \mathrm{m})$ and in biceps femoris muscle $(55.3 \mu \mathrm{m})$ than was shown for K2 and P33 ducks herein.

In biceps femoris muscles of P33 ducks, greater diameters of $\alpha \mathrm{W}$ and $\beta \mathrm{R}$ muscle fibres were found than in K2 ducks, which was due to the greater weight of these muscles in the Pekin ducks. Breast muscles of females in both flocks were characterized by similar weight, and by similar and small thickness of muscle fibres. Small fibre size of meat from K2 and P33 ducks is considered technologically desirable. Also PAKOCIŃSKA et al. (1972) obtained a greater diameter of pectoralis superficialis muscle fibres (from 30.7 to $32.5 \mu \mathrm{m}$ ) in the coot (Fulica atra). However, the birds studied by these authors were flight birds, which must have influenced the greater diameter of muscle fibres.

Meat quality studies are important from the consumer's point of view. The advantages of K2 ducks compared to P33 ducks are: a great proportion of breast muscles in carcass, which are characterized by a small diameter of white muscle fibres $(\alpha \mathrm{W})$ and 
darker colour of muscles, typical of game meat. One disadvantage of the Miniduck is the high content of skin with subcutaneous fat in carcass. P33 ducks are characterized by a large content of leg muscles in carcass and low fatness, indicating a considerable dietetic value. The meat of ducks from both conservative flocks showed normal values of $\mathrm{pH} 15 \mathrm{~min}$ and $24 \mathrm{~h}$ postmortem, which attests to the absence of PSE and DFD condition.

\section{Conclusions}

Ducks of the experimental flocks were characterized by considerable dressing percentage that was higher in females than in males. Very good musculature of breast was confirmed in K2 ducks and of legs in P33 ducks, as well as low content of skin with subcutaneous fat in $\mathrm{P} 33$ ducks. Values of $\mathrm{pH}_{15}$ and $\mathrm{pH}_{24}$ determined in breast muscles in both flocks were lower than in leg muscles. $\mathrm{pH}_{15}$ values of breast muscles and leg muscles measured 15 min postmortem were greater than those found after 24-h storage of cooled carcasses.

K2 birds were characterized by darker colour (lower $\mathrm{L}^{*}$ value) of breast muscle and higher redness $\left(a^{*}\right)$ and yellowness $\left(b^{*}\right)$ compared with muscles of P33 ducks. Measurements of $\alpha \mathrm{W}$ and $\beta \mathrm{R}$ muscle fibres in pectoralis supeficialis and biceps femoris muscles of K2 and P33 females revealed their small size, and in both flocks lower fibre diameters were found in pectoralis superfircialis than in biceps femoris muscle.

\section{References}

ASHMORE, C. R.; DOERR, L.:

Comparative aspects of muscle fiber types in different species. Experimental Neurology, 31 (1971), 408-418

BAÉZA, E; DE CARVILLE, H; SALICHON, M. R; MARCHE, G; LECLERCQ, B.:

Effects of selection, over three and four generations, on meat yield and fatness in Muscovy ducks. Br. Poultry Sci., 38 (1997), 359-365

BAÉZA, E; LISTRAT, A.:

Effect of selection on Muscovy duck meat. Proc. $15^{\text {th }}$ Europ. Symp. on the Quality of Poultry Meat, Kusadasi (2001), 35-37

BIESIADA - DRZAZGA, B; GÓRSKI, J; WITAK, B.:

Effects of feeding and age on thickness of muscle fibre in meat ducks of the A44 breed. Proc. $21^{\text {st }}$ World's Poultry Congr., Montreal , CD ROM (2000)

BROOKE, M. H.:

Some comments on neural influence on the two histochemical types of muscle fibers. Physiol. Biochem. Muscle Food, 2 (1970), 131-153

CHEN MING-TSAO; SUN-SAN, L; LIANG CHUAN, L.:

Effect of stresses before slaughter on changes to the physiological, biochemical, and physical characteristics of the duck muscle. Br. Poultry Sci., 32 (1991), 997-1004

CRAWFORD, R.D.:

Gene resources: global view of inventory and conservation. Proc. $10^{\text {th }}$ Intern. Symp. on Current problems in avian genetics, Nitra (1993), 131-136

DUBOWITZ, V; BROOKE, M.H; NEVILLE H, E.:

Muscle Biopsy. A modern Approach. Ed. by W. B. SAUNDERS Company Ltd., London, Philadelphia, Toronto (1973)

EVALUATION OF $20^{\text {th }}$ TEST IN REARING OF DUCK [in Czech] : International Station of Control and Research on Poultry, Ivanka at the Danube (1989)

FLETCHER, D. L; SCHREURS, F. J. G; UIJTTENBOOGAART, T. G.:

Chemically induced stress and post mortem physiology in broiler chickens. Proc. $19^{\text {th }}$ World's Poultry Congr., Amsterdam (1992), 365-368

GIANFALDONI, D; CAMPODONI, G; GIULIOTTI, L; PREZIUSO, G; SACCHI, P; TURI, R. M; ROMBOLI, I.: 
B-Agonists in muscovy drakes : Meat characteristics and residues in some organs and tissues. Proc. $9^{\text {th }}$ GÓRSKI, J.: Europ. Poultry Conf., Glasgow (1994), 215-216

Effect of mating Pekin ducks on body weight and thickness of some muscle fibres [in Polish]. Zesz. Nauk. WSRP Siedlce, 40 (1995), 115-126

ISGUZAR, E; KOCAK, C; PINGEL, H.:

Growth, carcass traits and meat quality of different local ducks and Turkish Pekins. Arch. Tierz., Dummerstorf 45 (2002), 1-6

KŁOSOWSKA, D; BERNACKI, Z; ELMINOWSKA-WENDA, G.:

Microstructure characteristics of pectoralis muscle and carcass parameters in male ducks of two genetic groups. $1^{\text {st }}$ World Waterfowl Conf., Taichung (1999), 545-551

KSIĄŻKIEWICZ, J.:

Miniduck [in Polish]. Biul. Inf. COBRD, Poznań 21 (1982), 23-30

KSIĄŻKIEWICZ, J.:

Reproductive and meat characteristics of Polish ducks threatened with extinction. Czech J. Anim. Sci. 47 (2002), 401-410

KSIAZŻKIEWICZ, J. M.:

Comparison of reproduction and meatiness traits in light type of ducks of four conservative flocks over eight generations. Arch. Tierz., Dummerstorf 46 (2003), 377-389

KSIĄŻKIEWICZ, J; KONTECKA, H.:

Relationships between body weight and measurements and some carcass components in Pekin-type ducks from conservative groups [in Polish]. Rocz. AR Pozn., 246 (1993), 31-43

KSIĄŻKIEWICZ, J; MAZANOWSKI, A.:

A characteristic of reproductive traits of ducks from conservative groups [in Polish]. Zesz. Nauk. Drob., 1 (1984), 17-27

MAIJALA, K.:

Potential practical uses of genetic reserves. Proc. Inter. Symp. on Conservation Measures For Rare Farm Animal Breeds. Balice near Cracow (1995), 11-20

PAKOCIŃSKA, J; SMOLIŃSKA, T; GÓRSKA, I.:

Technological characteristics of mallard duck (Anas platyrhynchos) and coot (Fulica atra) carcasses and meat [in Polish]. Zesz. Nauk. WSR Wrocław, Zoot., 97 (1972) :18

PIKUL, J.:

Technological evaluation of poultry industry raw materials and products [in Polish]. Wyd. AR Pozn (1993)

PINGEL, H; BIRLA, M.:

Effect of preslaughter factors on carcass quality in waterfowl [in Polish]. Pr. Bad. Zakł. Hod. Drob., 9 (1981), 121-126

POWELL, J. C.:

The possibilities for genetics improvement of commercial production characteristics and carcass quality in the meat duck. Duck Production Science and World Practice. Ed. by D. J. Farrell and P. Stapleton, Univ. New England, Armidale (1986), 184-192

RENERRE, M.:

Biochemical basis of fresh meat colour. Proc. $45^{\text {th }}$ Inter. Congr. of Meat Science and Technology. Yokohama (1999), 344-351

SMITH, D.P; FLETCHER, D.L; PAPA, C. M.:

Post-mortem biochemistry of pekin duckling and broiler chicken pectoralis muscle. Poultry Sci. 71 (1992), 1768-1772

STAŠKO, J.:

Variation in parameters at the duck breeding. Proc. $8^{\text {th }}$ Poultry Conf., Barcelona (1990), 497-500

WOŁOSZYN, J.:

Physicochemical and technological characteristics of muscles of force-fed ducks [in Polish]. Wyd. Akademii Ekonomicznej Wrocław, Dr Sci. thesis. (2002), 5-136

WORLD WATCH LIST FOR DOMESTIC ANIMAL DIVERSITY :

FAO, UNDP, $3^{\text {rd }}$ edition (2000), 3-73, 351

Received: 2003-09-09

Accepted: 2004-06-18

Authors address

Dr. TOMASZ KISIEL, Prof. Dr. habil. JULIUSZ KSIĄŻKIEWICZ

Department of Waterfowl Breeding Dworzyska, National Research Institute of Animal Production, 62-035 Kórnik near Poznań

Poland

E-Mail kiisiel@poczta.onet.pl 